\title{
LABORATORY STUDY OF ELECTROCOAGULATION FOR COD REMOVAL FROM WASTEWATER
}

\author{
Khalid S. Hashim ${ }^{1}$ and Bareq Abdulhadi ${ }^{2}$ \\ ${ }^{\mathbf{1}}$ School of Civil Engineering and Built Environment, Liverpool John Moores \\ University, Liverpool, UK. Email: K.S.Hashim@ljmu.ac.uk \\ ${ }^{2}$ School of Civil Engineering and Built Environment, Liverpool John Moores \\ University, Liverpool, UK. Email: B.A.Abdulhadi@2017.ljmu.ac.uk \\ HTTPS://DOI.ORG/10.30572/2018/KJE/130106
}

\begin{abstract}
The current work investigates the ability of the new aluminium-based electrocoagulation (EC) cell to remediate chemical oxygen demand (COD) from synthetic wastewater. The experimental work was carried out using a rectangular EC cell $(10 \mathrm{~cm}$ in length, $9.5 \mathrm{~cm}$ in width, and $7 \mathrm{~cm}$ in depth). The EC cell was supplied with six perforated aluminium electrodes; four of these electrodes were used in the treatment methods (connected to DC electrical current), while the first and the last electrodes were used as baffle plates (to mix water). This lab-scale unit was used to treat synthetic wastewater having $300 \mathrm{mg} / \mathrm{l}$ of COD, considering the effect of the treatment time and initial $\mathrm{pH}$. After 40 minutes of treatment at a $\mathrm{pH}$ of 7 and a current density of $10 \mathrm{~A} / \mathrm{m}^{2}, 51 \%$ of COD was removed by the new EC unit. The results also revealed that the removal of the COD is positively influenced by the increase of the applied current density and/or treatment time.
\end{abstract}

KEYWORDS: Wastewater; COD; electrocoagulation. 


\section{INTRODUCTION}

It is an undeniable fact that Earth's planet faces serious pollution phenomena that represent a direct threat to the existence of humankind. For instance, the rapid increase in world population and industrial activities resulted in the huge production of liquid and solid wastes (Singh and Singh, 2017), which significantly polluted the natural resources, altered the ecosystems, and changed the climate of the Earth planet. One of the most serious forms of pollution is water pollution, where the production of huge volumes of wastewater significantly limits freshwater availability (Flörke et al., 2013). It has been reported that by 2050 more than $50 \%$ of the world inhabitants will not have enough freshwater (Fogden and Wood, 2009). Thus, different water treatment methods have been experienced to minimise the increasing pollution phenomenon, such as biological and chemical methods. Electrocoagulation (EC) process is defined as in situ production of coagulants by passing electricity through sacrificial metallic electrodes, which eliminates the need for metal salts (Hakizimana et al., 2017). This treatment method has received a big deal of attention as a promising alternative for the traditional methods due to many merits. For example, it does not require metal salts to achieve the treatment process as it depends on sacrificial metallic electrodes to produce the required coagulants, which means it does not generate secondary pollutants. Because it depends on electrical attraction force to produce flocs, it significantly minimises the volume of the produced sludge, which decreases the cost of sludge handling (Hakizimana et al., 2017). It is noteworthy to mention that the handling of solid waste is a costly and time-consuming process. Additionally, its ability to remove, up to $95 \%$, of different pollutants in a relatively short time has been proved. Due to these attractive merits, the electrocoagulation method has been applied to remove different pollutants from water and industrial and municipal wastewaters. For example, Yilmaz et al. (2005) investigated the removability of boron from wastewater by EC. To achieve that, a batch flow EC reactor with a volume of $1024 \mathrm{~cm}^{3}$ and $\mathrm{Al}$ electrodes was employed to remove boron, $100 \mathrm{mg} / \mathrm{L}$, wastewater containing diverse operating parameters. The highest removal efficiency was obtained at an initial $\mathrm{pH}$ of 8 , a current density of $3 \mathrm{~mA} / \mathrm{cm}^{2}$, and $0.015 \mathrm{~mole} / \mathrm{L}$ of $\mathrm{CaCl}_{2}$ (as an electrolyte). Gao et al. (2010) treated synthetic water samples $1.2-1.4 \times 10^{9}$ cells $/ \mathrm{L}$ of M. Aeruginosa (algae) using aluminium and iron electrodes with a current density range of $0.5-5 \mathrm{~mA} / \mathrm{cm}^{2}$ and initial $\mathrm{pH}$ from 4 to 10 . The obtained results demonstrated that $100 \%$ of algae was removed using the aluminium electrodes after $45 \mathrm{~min}$ at a current density of 1 $\mathrm{mA} / \mathrm{cm}^{2}$, initial $\mathrm{pH}$ of $4-7$, and power consumption of $0.4 \mathrm{~kW} / \mathrm{m}^{3}$. Govindan et al. (2015) used a batch flow EC cell, supplied with two different types of electrodes, Al-Fe (anode-cathode) 
and $\mathrm{Fe}-\mathrm{Fe}$, to remediate synthetic water from nitrates. The nitrate removal was studied at different current densities ( 0 to $25 \mathrm{~mA} / \mathrm{cm}^{2}$ ), treatment time (0 to $180 \mathrm{~min}$ ), and electrolyte concentration ( 0 to $500 \mathrm{ppm}$ ). The outcomes showed that, after $180 \mathrm{~min}$ of electrolysing at 25 $\mathrm{mA} / \mathrm{cm}^{2}$ and with $100 \mathrm{ppm}$ of $\mathrm{NaCl}$, the nitrate removal was $92 \%$ for $\mathrm{Al}-\mathrm{Fe}$ electrodes and $80 \%$ for Fe-Fe electrodes.

Although, like all treatment methods, the electrocoagulation methods have some disadvantages, such as the lack of reactors design; the majority of the available reactors, nowadays, are consist of a simple container and rectangular or square electrodes (Hashim et al., 2017; Un et al., 2013). Hence, the current study has been commenced to validate the performance of a new electrocoagulation cell. Thus, this study aims to validate the performance of a new bench scale electrocoagulation cell that employs perforated aluminium electrodes as mixers, which eliminates the need for external mixers and decreases the operational cost as a consequence, and also to validate its ability to decrease the chemical oxygen demand (COD) in wastewater.

\section{METHODOLOGY}

\subsection{Electrocoagulation reactor}

The new electrocoagulation cell consists of a Perspex container with a net volume of $665 \mathrm{~cm}^{3}$ (10 $\mathrm{cm}$ in length, $9.5 \mathrm{~cm}$ in width, and $7 \mathrm{~cm}$ in depth). This container is supplied with six perforated aluminium electrodes $(7 \mathrm{~cm}$ in height and $9.9 \mathrm{~cm}$ in width). Each electrode has 9.4 $\mathrm{cm}$ in width and $8 \mathrm{~cm}$ in height (the extra $1 \mathrm{~cm}$ is for the holder) and 36 holes $(0.4 \mathrm{~cm}$ in diameter), Fig. 1.

These electrodes were partially submerged in the synthetic wastewater. Four of these electrodes were used in the treatment methods (connected to DC electrical current), while the first and the last electrodes were used as baffle plates (to mix water). This lab-scale unit was used to treat synthetic solutions, $500 \mathrm{~mL}$ in volume, having $300 \mathrm{mg} / \mathrm{l}$ of COD, considering the effect of the initial $\mathrm{pH}$ and treatment time. 


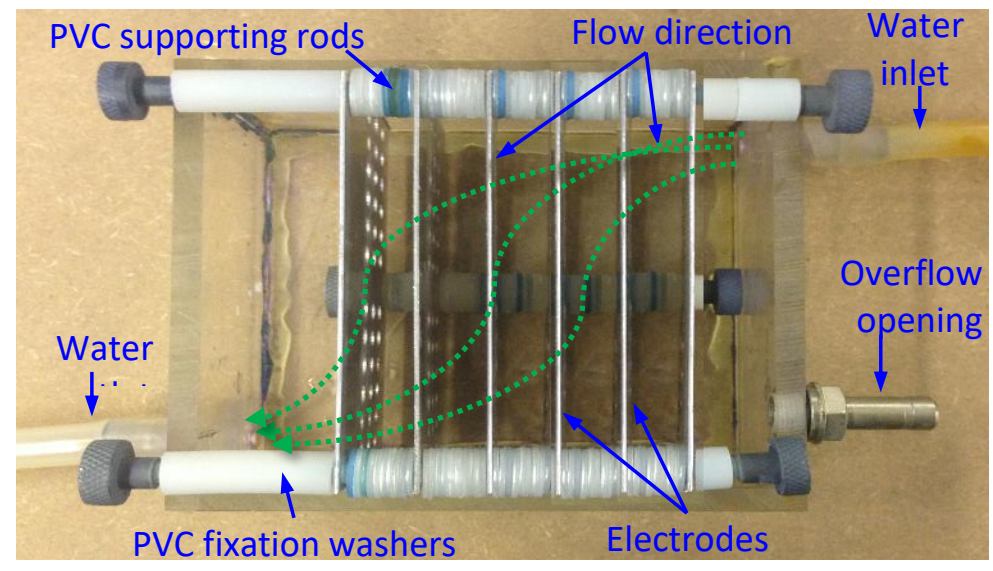

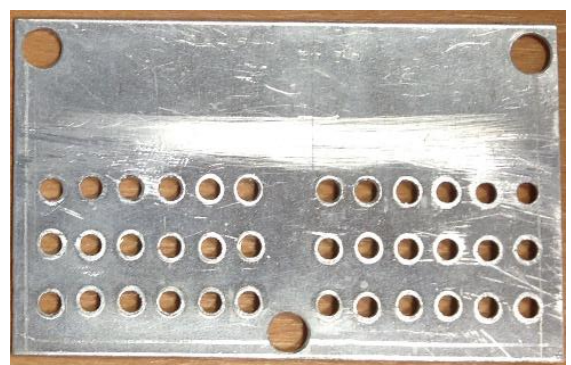

(B)

(A)

Fig. 1. A) The new electrocoagulation cell, B) the electrode.

\subsection{Water samples and treatment process}

A measured volume of synthetic wastewater, $20 \mathrm{~L}$, were prepared using the standard methods stated in the literature (Xu and Cui, 2019). The prepared sample had an average COD concentration of $300 \mathrm{mg} / \mathrm{l}$, and they were refrigerated, $2{ }^{\circ} \mathrm{C}$, to be used later. The COD was measured using a standard Hach-Lang COD cuvette test and a spectrophotometer (HachLang, Model: DR 2800).

The electrocoagulation process was started by applying DC current using a rectifier (Model: PS 3010). A peristaltic water pump (model:504-U) was used to circulate water. The effects of treatment time (0-60 min) and initial $\mathrm{pH}(3-9)$ were investigated. The initial $\mathrm{pH}$ of the sample was adjusted to the required level using $\mathrm{NaOH}$ or $\mathrm{H}_{2} \mathrm{SO}_{4}$. All experiments were commenced at a constant current density $\left(10 \mathrm{~A} / \mathrm{m}^{2}\right)$, the distance between electrodes $(1 \mathrm{~cm})$, and room temperature $\left(20 \pm 1^{\circ} \mathrm{C}\right)$.

Most of the studied ranges, such the $\mathrm{pH}$ range and water temperature, were adopted from the literature.

\section{RESULTS}

\subsection{Effects of treatment time}

To investigate the impact of treatment time on the removal of COD from wastewater, applied current density, initial $\mathrm{pH}$, and distance between electrodes were kept constant at $10 \mathrm{~A} / \mathrm{m}^{2}, 7$, and $1 \mathrm{~cm}$, respectively, while the treatment time varied from 0 to 60 minutes. As shown in Fig. 2, the new electrocoagulation cell requires $60 \mathrm{~min}$ to remove $57 \%$ of the COD. Generally, the COD removal increased rapidly during the first $40 \mathrm{~min}$ of treatment (from 0 to about $51 \%$ ). Then, a slight rise in the removal of COD was noticed during the last 20 min of 
treatment. This change in the removal of COD is because of the growth of a passive layer on the surface of aluminium electrodes that minimises the production of aluminium ions and decreases the removal efficiency as a consequence (Mansour et al., 2013; Heffron, 2015).

A ttreatment time of $40 \mathrm{~min}$ has been considered, in the current study, to run the rest

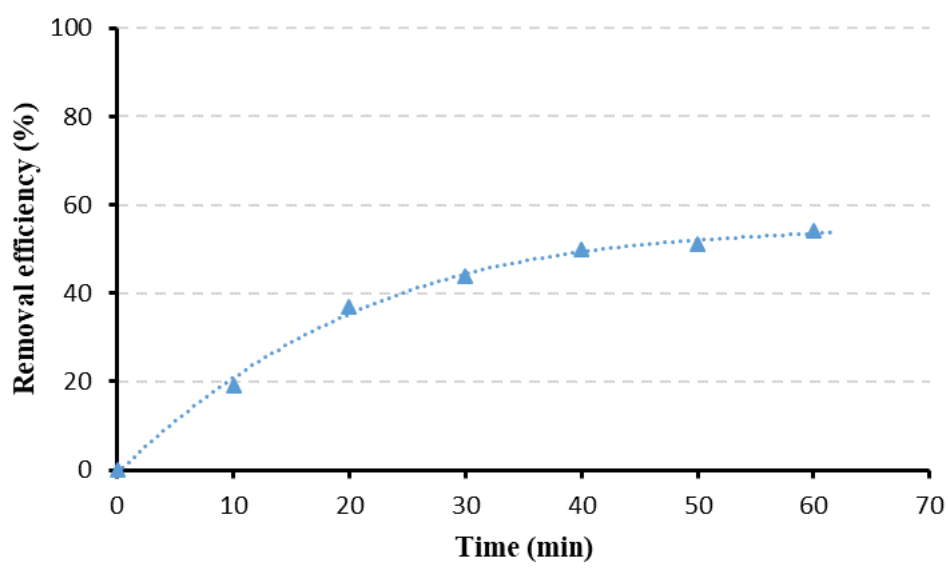

experiments.

Fig. 2. Effect of treatment time on COD removal.

\subsection{Effects of initial pH}

The $\mathrm{pH}$ of the solution being treated has significant importance as it affects the chemistry of the solution and controls the hydrolysis of the produced coagulants (Zhao et al., 2014). Thus, to examine the impact of the initial $\mathrm{pH}$ level on COD removal, several sets of experiments were commenced at different initial $\mathrm{pH}$ values $(3,5,7$, and 9), keeping the rest of the parameters constant (current density $\left(10 \mathrm{~A} / \mathrm{m}^{2}\right.$, distance between electrodes $(1 \mathrm{~cm})$, and treatment time (40 min)).

Fig. 3 indicates that the best removal of COD could be reached in a neutral environment $(\mathrm{pH}$ of 7). It can be seen, from this figure, that the COD removal increased gradually, from 42 to $51 \%$, as the initial $\mathrm{pH}$ increased from 3 to 7 . Then, the removal of COD decreased again to $46 \%$ reach as the initial $\mathrm{pH}$ increased from 7 to 9 . The possible explanation of this behaviour, as mentioned above, is the effect of the $\mathrm{pH}$ on the hydrolysis of the produced coagulants. Where, in neutral media, the predominant aluminium hydroxides have good adsorption capacity. While in alkaline or acidic media, the predominant aluminium hydroxides have low adsorption capacity (Un et al., 2013).

It is very clear that the $\mathrm{pH}$ of the solution being treated plays a central role in the electrocoagulation process. Therefore, based on the recent developments in sensing 
technology, the authors recommend applying this technology in the electrocoagulation cell to monitor and control the $\mathrm{pH}$ level during the treatment process.

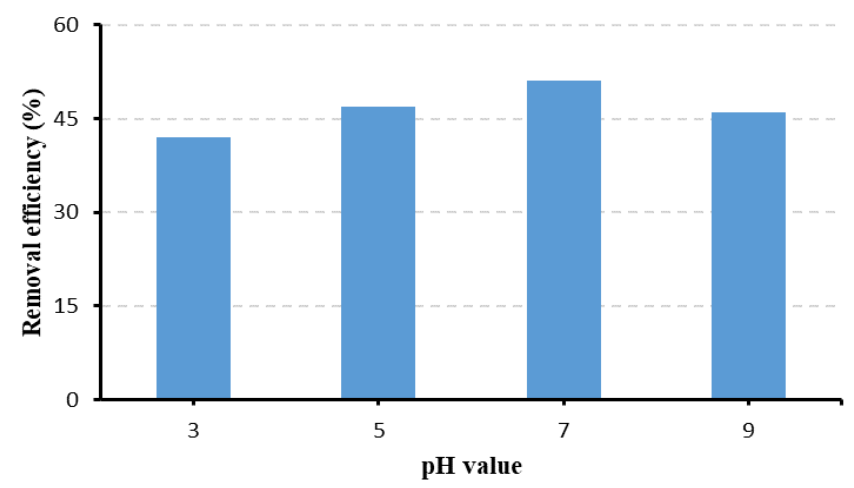

Fig. 3. Effect of the initial $\mathrm{pH}$ on COD removal

\section{CONCLUSIONS}

Experiments were commenced to validate the ability of a new electrocoagulation cell to remove chemical oxygen demand (COD) from water. The obtained results from the current study confirmed the applicability of this new cell for the mentioned purpose. Additionally, it has been noticed that the performance of this new cell, in terms of COD removal, could be enhanced by increasing the treatment time and keeping the $\mathrm{pH}$ of the solution being treated at a neutral level.

Finally, the authors recommend the application of this new cell to remove other pollutants from solutions and the application of sensing technology in the electrocoagulation cells to monitor and control the $\mathrm{pH}$ level during the treatment process.

\section{REFERENCES}

Flörke M., E. Kynast, I. Bärlund, S. Eisner, F. Wimmer, and J. Alcamo, "Domestic and industrial water uses of the past 60 years as a mirror of socio-economic development: A global simulation study," Global Environmental Change, vol. 23, no. 1, pp. 144-156, 2013.

Fogden J., and G. Wood, "Access to Safe Drinking Water and Its Impact on Global Economic Growth: A study for Halosource", The Open Corrosion Journal, vol. 2, pp. 45-50, 2009.

Gao S., J. Yang, J. Tian, F. Ma, G. Tu, and M. Du, "Electro-coagulation-flotation process for algae removal," J Hazard Mater, vol. 177, no. 1-3, pp. 336-43, May 152010.

Govindan K., M. Noel, and R. Mohan, "Removal of nitrate ion from water by electrochemical approaches," Journal of Water Process Engineering, vol. 6, pp. 58-63, 2015. 
Hakizimana J. N., B. Gourich, M. Chafi, Y. Stiriba, C. Vial, P. Drogui, and J. Naja, "Electrocoagulation process in water treatment: A review of electrocoagulation modeling approaches", Desalination, vol. 404, pp. 1-21, 2017.

Hashim K. S., A. Shaw, R. Al Khaddar, M. Ortoneda Pedrola, and D. Phipps, "Defluoridation of drinking water using a new flow column-electrocoagulation reactor (FCER) Experimental, statistical, and economic approach," Journal of Environmental Management, vol. 197, pp. 80-88, Jul 152017.

Heffron J., "Removal of Trace Heavy Metals from Drinking Water by Electrocoagulation," MSc thesis, The faculty of the Graduate School, Marquette University, 2015.

Mansour S. E., E.-S. M.Negim, I. H. Hasieb, O. A. Desouky, R. Abdykalykova, and M. Beisebekov, "Removal of Cadmium Pollutants in Drinking Water Using Alternating Current Electrocoagulation Technique," Global Journal of Environmental Research, vol. 7, no. 3, pp. 45-51, 2013.

Singh R.L., and P.K. Singh, "Global environmental problems. Principles and applications of environmental biotechnology for a sustainable future", Springer, 2017.

Un U. T., A. S. Koparal, and U. Bakir Ogutveren, "Fluoride removal from water and wastewater with a bach cylindrical electrode using electrocoagulation," Chemical Engineering Journal, vol. 223, pp. 110-115, 2013.

Xu Q. and L. Cui, "Removal of COD from synthetic wastewater in vertical flow constructed wetland," Water Environment Research, vol. 91, no. 12, pp. 1661-1668, 2019.

Yilmaz A. E., R. Boncukcuoglu, M. M. Kocakerim, and B. Keskinler, "The investigation of parameters affecting boron removal by electrocoagulation method," J Hazard Mater, vol. 125, no. 1-3, pp. 160-5, Oct 172005.

Zhao S., G. Huang, G. Cheng, Y. Wang, and H. Fu, "Hardness, COD and turbidity removals from produced water by electrocoagulation pretreatment prior to reverse osmosis membranes," Desalination, vol. 344, pp. 454-462, 2014. 